\section{Ute Poerschke}

The Pennsylvania State University 429 Stuckeman Family Building University Park, PA 16802 USA uxp10@psu.edu

Keywords: Gottfried Semper, functionalism, nineteenth century, algorithms, calculus, differential equations, infinity
Research

\section{Architecture as a Mathematical Function: Reflections on Gottfried Semper}

Abstract. In a lecture of 1853, the architect and architectural theorist Gottfried Semper (1803-1879) explained a work of art as a mathematical function. The lecture was published for the first time in 1884 and the equation for the work of art was presented there as $Y=F(x, y, z$, etc. $)$. Since then, several widely differing manuscripts, translations, and interpretations have appeared. The following essay describes Semper's equation, the variations and explanations he gave in his writings, and the interpretations by others that have followed up to the present. It discusses Semper's attempts to connect architecture with infinitesimal calculus, his mathematical background, and his desire to give architecture a scientific foundation through methods of systematic comparison and classification.

\title{
Introduction
}

The nineteenth-century discussion of architecture was shaped by the theme of the organic as contrasted with the mechanical, in reference to natural history, evolving biology, Romantic philosophy, and linguistics. The architect and architectural theorist Gottfried Semper (1803-79) found inspiration in these fields, too, especially in natural history. Deeply impressed by Georges Cuvier's and Alexander von Humboldt's developments of comparative methods in natural history, he wished to write a Vergleichende Baulehre (Comparative Architectural Theory).

In contrast to this frequently interpreted relationship between natural history and architecture in Semper's oeuvre, ${ }^{1}$ the present text attempts to link architecture with mathematics and more specifically with infinitesimal calculus. It will address Semper's fascination with this relatively new mathematical field, which had only been established in the early eighteenth century, and the role it played in Semper's architectural theory in relation to questions of style and the classification of architecture.

\section{Gottfried Semper's equation}

In 1884 Hans and Manfred Semper published the manuscripts of their father's lectures under the title Kleine Schriften (Minor Writings), including a lecture Semper gave in English in London on November 11, 1853, which Hans Semper translated under the title "Entwurf eines Systemes der vergleichenden Stillehre" (Outline for a System of Comparative Style Theory). For roughly a century, Semper theorists used this translation as the basis for their interpretations of his mathematical understanding of architecture, until in the 1980s Wolfgang Herrmann and Harry Francis Mallgrave pointed out in a number of publications that Semper's son had translated the English lecture incorrectly, combining and editing two different manuscripts, and hence distorted the lecture and, more specifically, his explanation of architecture as a mathematical function, published as $Y=F$ ( $x, y, z$ etc.) [Herrmann 1981: 154; Mallgrave, Rykwert and Semper 1983; Mallgrave 1996: 5]. 
To help understand the course of the interpretations, therefore, this passage is quoted first in its German version:

Jedes Kunstwerk ist ein Resultat, oder, um mich eines mathematischen Ausdruckes zu bedienen, eine Funktion einer beliebigen Anzahl von Agentien oder Kräften, welche die variablen Koefficienten ihrer Verkörperung sind.

$Y=F(x, y, z$ etc. $)$

In dieser Formel steht $\mathrm{Y}$ für das Gesamtresultat und $\mathrm{x}, \mathrm{y}, \mathrm{z}$ etc. stellen ebensoviele verschiedene Agentien dar, welche in irgend welcher Richtung zusammen oder aufeinander wirken, oder voneinander abhängig sind. Die Art dieser gegenseitigen Beeinflussung oder Abhängigkeit ist hier durch das Zeichen F (Funktion) ausgedrückt. ...

Es sind zwei Klassen von Einflüssen zu unterscheiden, welche bei der Entstehung eines Kunstwerkes bestimmend einwirken. Die erste derselben umfaßt diejenigen Anforderungen, welche in dem Kunstwerke selbst begründet sind und auf gewissen Gesetzen der Natur und des Bedürfnisses beruhen, die zu allen Zeiten und unter allen Umständen sich gleich bleiben.

Diese Klasse von Einflüssen bezeichnen wir mit dem Buchstaben F.

Die zweite Klasse umfaßt diejenigen Einflüsse, die wir als von außen her auf die Entstehung eines Kunstwerkes wirkend bezeichnen dürfen. Ihnen entsprechen in der oben angewendeten allgemeinen Formel die Buchstaben x, y, z etc. [Semper (1884) 1979: 267-269].

" $F$ (Funktion)" is described as the way the agents $x, y, z$, etc. influence or depend on each other, later also explained as motive (Motiv) [(1884) 1979: 269] and purpose ( $Z_{\text {weck }}$ [(1884) 1979: 274]. In particular, the term "purpose" raised questions about the quality of the translation, since Gottfried Semper didn't use the word "purpose" in any of his original manuscripts, but spoke instead of "the use of the things" [Mallgrave, Rykwert and Semper 1983: 13]. ${ }^{2}$ In the German translation, $F$ is explained with the example of a drinking cup, which will generally look the same regardless of its national origin, time, material, or fashion [Semper (1884) 1979: 269]. In contrast, $x, y, z$ etc., the external influences on a work of art, are unlimited in number but can be broken down in three groups: first, the materials and the ways of making; second, local and ethnologic influences, as well as climate, religion, politics and other national conditions; third, all personal influences of the client, artist or craftsman [Semper (1884) 1979: 271].

In 1983 Mallgrave published the two manuscripts originally written in English, which are held in the gta-Archiv at the ETH Zurich (Ms. 122 and Ms. 124). In Ms. 122, which according to Mallgrave is the version of the lecture that Semper delivered, the corresponding passage reads as follows:

Every work of art is a result, or, using a Mathematical Term, it is a Function of an indefinite number of quantities or powers, which are the variable coefficients of the embodiment of it.

$U=C x, y, z, t, v, w$.

... We must distinguish two different kinds of influences, which act upon the embodiment of an artistic work. 
The first class comprises the exigencies, of the work itself and which are based upon certain laws of nature and of necessity, which are the same at all times and under every circumstance.

The second class comprises such vehicles, which we may call outward influences acting upon the performance of a work of art.

That part of the Doctrine of Style, which treats of the first class, embraces the elementary Ideas or what the Artist calls the Motives of the things, and the early forms, in which these fundamental Ideas have been clothed.

... The second part of the Doctrine of Style comprehends chiefly local and personal Influences, such as the climate and physical constitution of a country, the political and religious institutions of a nation, the person or the corporation by whom a work is ordered, the place for which it is destined, and the Occasion on which it was produced. Finally also the individual personality of the Artist [Mallgrave, Rykwert and Semper 1983: 11-12]. ${ }^{3}$

The equation reads differently here. The two "influences" or "classes" described are not assigned in any clear way to $C$, on the one hand, and to $x, z, y, t, v, w$, on the other. Moreover, materials and the ways of making are not assigned to any class, and the example of the drinking cup is not mentioned. In particular, however, it is completely unclear whether $C$ stands for the function notation (the expression of a function) or a variable. Mallgrave explained the differences between Ms. 122 and the translation thus:

Hans Semper no doubt found his father's explanation of the formula vague or puzzling, for after presenting the mathematical analogy in his translation he rejected the text of this manuscript (Ms. 122) and turned to an explanation for the formula given in an earlier draft of the lecture (Ms. 124) [Mallgrave 1996: 218].

In Ms. 124, the passage reads as follows:

Every work of art is a result, or, using a mathematical term, it is a Function of an undefined number of agents or powers, which are the variable coefficients of the Embodiment of it.

$Y=C(x, y, z, t, v, w, \ldots)$

In this formula, $Y$ stands for the general Result, and $x, y, z, t, v, w$ represent as many different agents, which work together in a certain way which way is expressed here by the Greek letter $\mathrm{C}$ or function.

... By the letter $\mathrm{C}$ we may understand the exigencies of the work of industry or art in itself, which are based upon certain laws of nature and of necessity which is the same at all times and under every circumstance. A drinking cup for instance will be the same in its general feature for all nations and at all times; it will be in principle the same, if executed in wood, in Earthenware in glass in metal or whatever other material it may be no matter.

The elementary Idea of a work of art which is based upon its use and destination is independent upon fashion upon material and upon local conditions. The artists call this the motive of an object of art. 
... We come now to those coefficients of our result which I signified in the general formula by the letters $x, v, t, w$ etc. Those are the different vehicles which act upon the embodiment of our hands, and modify the appearances of the Elementary ideas. ... Their number is undefined, but they can be grouped into three distinct classes. Among these agents is one group which consists of the materials and the modes of execution, or the processes which come in question for their execution. The second Group comprises the local and ethnological influences upon artistical performances, the influences of Clime, religious and political institutions and other national conditions. The third Group is that, which includes all the personal influences ... from those who are the commanders of the works, or from the artists and the practical performers of the last [Mallgrave, Rykwert and Semper 1983: 18-19].

From Ms. 124 it is clear that $\mathrm{C}$ is to be understood as a function notation (an algorithm). Thus it could be said that Ms. 124 sheds light on Ms. 122, and that would explain why Hans Semper introduced this passage into his translation. This, however, might raise the question why Gottfried Semper did not write $F$ rather than $C$, since the formula $Y=F(x, y, \ldots)$ would have made it perfectly clear that $F()$ was a function notation.

In addition to Mss. 122 and 124, there is another manuscript at the ETH Zurich (Ms. 179, “Theorie des Formell-Schönen”, Eng. trans: The Attributes of Formal Beauty), which was cited by Mallgrave as evidence that Semper's son misinterpreted the equation. It was written upwards of 1855 and published in its original German version in 1981 and in English in 1984, in both cases by Herrmann. Being very close to the German original, the English version is quoted here:

However, there is also a stylistic conception of what is beautiful in art - this considers the object ... as a unit, as the uniform result or function of several variable values that unite in certain combinations and form the coefficients of a general equation; by giving these variables the values appropriate to the particular case, one will arrive at the solution of the problem:

$\mathrm{U}=\mathrm{C}(x, y, z, t, v, w \ldots)$

... What are these variable coefficients, these elements of the general formula whose result we deem to be a work of art? Their number is indeterminable; we shall touch upon only some of the most important ones.

They can be divided into two distinct classes: first, those elements that are contained, as it were, in the work itself and that comply with certain compelling natural and physical laws that are the same under all circumstances and at all times; second, those elements that have an influence on the genesis of the work of art from the outside.

To the first class belongs above all the purpose of the object ... . Also belonging to this class is the material ... . Third, the utensils with which the work is to be done and the various processes for treating the material ....

The extrinsic coefficients of the artistic form of representation are more varied. To be taken into account first are local and personal influences and factors, such as climate, topography, national education, political-religious and social institutions, historical memories and traditions, local environment ..., the person or group who commission the work .... Among numerous other influences there are also incidental circumstances that have an effect on the work in hand. Finally, the 
artist's hand, his individual taste and artistic attitude as essential factors in the creation of a work of art, are among the extrinsic influences [Hermann 1984: 241-242].

This quote presents a fourth version of the equation, again slightly different from the others. And again it is not completely clear whether $C$ and $(x, y, z, t, v, w \ldots)$ are the representatives of the two classes named. If they were, why would the first class be identified only by the letter $C$ and the second by many letters? Moreover, Semper says neither that $\mathrm{C}$ represents the function notation, as he did in Ms. 124, nor that it is a variable. It is also interesting to see how the position of material and its treatment changes: in the son's translation and in Ms. 124 they belong to the second class; in Ms. 122 they are not assigned; and in Ms. 179 they are included in the first class. This changing position is an example of how permeated Semper's theoretical work was by the question of whether material and its treatment represent internal or external qualities of a work, that is, whether they determine the form or merely modify it. The organization of his magnum opus, Der Stil in den technischen und tektonischen Künsten (Style in the Technical and Tectonic Arts) of 1860-63, raises this question, too, since the chapters "Textile Kunst" (Textile Art), "Keramik" (Ceramics), "Tektonik" (Tectonics), "Stereotomie" (Stereotomy), and "Metallotechnik" (Metallurgy) are not focused on materials, but on means of production that admit of several materials.

When all four texts are compared, the problem arises that the equations can be interpreted in two different ways, resulting from the fact that it is not clear whether the formula is a general equation such as $y=f(x)$ or a specific equation such as $y=a x^{2}$. In the first case, Semper's $C$ would be a function notation or the correspondence rule between variables; in the second, it would be a variable. Semper's son seems to have assumed the former, apparently basing that on the reading of Ms. 124, and thus changed the letter C to F. Mallgrave, in contrast, chose the latter based on Ms. 179 and consequently had to conclude that Mss. 122 and 124 are "incompatible" [Mallgrave 1996: 218]. In what follows the question of what speaks for the one reading and what for the other will be addressed.

With regard to the first reading, one could ask how a motive or a design idea could serve to define a function or correspondence of variables. To better understand this, we can refer to a discussion in a text on logic by Gottlob Frege, "Funktion und Begriff" (Function and Concept) written in 1891, although it was not published until almost forty years after Semper's lecture. Frege argued that functions and concepts have corresponding meanings. He offered as an example the concept "capital" for which he defined "the capital of $x$ " as "the expression of a function." If "German Empire" is input for $x$, the result is "Berlin" [Frege (1891) 1980: 31-32]. Thus, Frege's "concept" or functional expression states how the variables and the result relate to one another. Yet a concept is never a concrete thing. Viewed as a function, it is "incomplete, in need of supplementation, or unsaturated" [Frege (1891) 1980: 24], that is, it requires values that complete it to a concrete object, which can then be experienced through the senses. In mathematics, the incompleteness of a function $F(x)$, or in Frege's words, "the need of the function for supplementation" is represented by the parentheses, "the space between these is meant to receive the sign for the argument" [Frege (1891) 1980: 27-28]. Relating this thought back to Semper's equation, his "motive" can be interpreted in the sense of Frege's "concept," in that both the motive and the concept are incomplete. One could easily conclude from Semper's use of the parentheses that his notation $\mathrm{C}(\ldots)$ is meant as 
an unsaturated functional expression and the letters in the brackets as the values needed to complete the motive.

One might come to a different conclusion when reading Semper's Ueber die bleiernen Schleudergeschosse der Alten (On the Leaden Slingshot Missiles of the Ancients) $[1859]^{4}$ in which he made heavy use of equations. That treatise, in which Semper attempted to describe the forms of projectiles mathematically, was published in 1859 , but it was written at the same time as the aforementioned lecture and was completed in 1855, after he had asked mathematicians to read it and then revised it. In that text Semper formulated the equation $W=d . N$., where $W$ is the effect (Wirkung), $d$ the density of the medium, and $N$ the "other coefficients of the value for $W$, whatever their nature" [Semper 1859: 10]. Like all the other formulas in this text, all of the letters on the right side signify coefficients, and none of them expresses the functional correspondence. In its generality, the formula is very similar to the one in the 1853 lecture. It is an example of Semper formulating equations in which all letters signify coefficients rather than a functional sign; however, no brackets are used in this equation.

Other Semper texts do not feature an equation but do have "coefficients" and "influences" and, depending on how they are classified, it is possible to argue for one of the two readings. 5 Semper wrote as early as 1843 that "architecture too is based on certain normal forms that - conditioned by an original idea - permit in constant reappearance an infinite variety depending on special purposes and on further determining circumstances" [Herrmann 1976: 216-217; also quoted in Ms. 55 in Herrmann 1981: 184]. Semper distinguished here between an "original idea" and "special purposes," and this can be connected to two lines of thought. First, this distinction supports Mallgrave's criticism that Semper's son wrongly equated "idea" and "purpose" and thus abetted Gottfried Semper's reception as a materialist. It could be objected, however, that Semper himself did not in fact always clearly separate the concepts of "idea" and "purpose." It seems rather that Semper distinguished between two different kinds of purposes: on the one hand, traditional, culturally evolved purposes that determine the idea; on the other hand, current, practical, more specified purposes. In this view, a fundamental purpose thus belongs to the idea or the motive of an object as a vessel, for example - and should be distinguished from a more special purpose - for example, as a bucket or scoop in flowing water.

Second, in this quotation Semper listed not just two but three conditions for a work, namely, the "original idea," "special purposes," and other "circumstances." In Wissenschaft, Industrie und Kunst (Science, Industry, and Art [(1852) 1989]) as well, Semper explicitly treats "three parts": first, the "the primordial motives (Urmotiven) and the primary forms derived from them"; second, the "means" and the "material"; and third, the "local, temporal, and personal influences on form extrinsic to the work of art." A stylistic work is composed of these three parts, since "Style means giving emphasis and artistic significance to the basic idea and to all intrinsic and extrinsic coefficients that modify the embodiment of the theme in a work of art" [Semper (1852) 1989: 136-138].

If this understanding of three parts is to be associated with the formula, one has to ask where the "original idea," "primordial motive" or "primary form" is located in the equation. If $C$ and $x, y, z$ are taken by the internal and external coefficients, respectively, then one would have to conclude that the idea, motive or primary form is the equation itself. That definition of style can only be reconciled with the second reading presented above. That is the conclusion to which Mallgrave arrived. 
The mathematical parallel is found in Style in the Technical and Tectonic Arts as well. As an "empirical theory of art," the text

will not apprehend and explain the works of art of different periods and countries as facts but rather it will expand upon them, as it were, by identifying in each the necessarily different values of a function composed of many variables. It will do this primarily with the intention of revealing the inner law governing the world of the art-form, just as it governs the world of nature. ... Nothing is arbitrary; everything is conditioned by circumstances and relations [(1860) 2004: 71-72]. ${ }^{8}$

Function can be understood as the inner law of becoming that remains to be discovered.

\section{The place of mathematics in Semper's life}

Is Semper's equation proof of his taking a materialistic and deterministic view of art, as he was repeatedly accused of doing?? As a way of approaching this question, it may be helpful to examine what Semper actually knew about mathematics and see if his life experiences provide indications of his understanding of the connection between infinitesimal calculus and architecture.

Semper, born in 1803, showed a talent for mathematics as a student. The director of his school recommended that he study under the mathematicians Carl Friedrich Gauss and Bernhard Friedrich Thibaut at the University of Göttingen, and initially Semper followed this advice (see [Mallgrave 1996: 12; Herrmann 1990]. In a letter to his parents dated August 1824, he stated that he had been preoccupied with mathematics for eight months [Mallgrave 1996: 13]. Surviving loan cards from the university library prove that Semper had borrowed books on mathematics, mechanics, and military science. At the same time, Semper also confessed to having lost his taste for the subject and preferring to dedicate himself to more practical tasks [Mallgrave 1996: 14]. Beginning around this time he began to search for new career goals and, in addition to a military career, he seriously considered hydraulic engineering, for which he would have needed extensive knowledge of mathematics used in fluid mechanics as well as the mathematical analysis of motion and acceleration. ${ }^{10}$ During the next two decades, Semper studied architecture in Paris from late 1826 onward, made a long journey to Italy, Sicily and Greece from 1830 to 1833 , and taught as a professor and was increasingly active as an architect from 1834 to 1849 . His interest in mathematics, and especially his knowledge of hydraulic engineering, did not become evident again until the publication in 1859 of his Ueber die bleiernen Schleudergeschosse der Alten. That work clearly reveals Semper's passion of mathematics. Its subtitle, Ein Versuch die dynamische Entstehung gewisser Formen in der Natur und in der Kunst nachzuweisen (An Attempt to Demonstrate the Dynamic Origin of Certain Forms in Nature and Art), testifies to Semper's desire to analyze optimal forms - from nature as well as from art - scientifically. He introduced the text by stating his conviction "that every true artistic form must be the expression of a certain law of innermost necessity, just as is surely the case for natural forms" [Semper 1859: 1-2].

The concept of infinitesimal calculus, for example in the descriptions of tangents and areas of curves, can already be found in antiquity [Jahnke 1999: 5-6]. Semper's enormous interest in antiquity led him to speculate, in his text on leaden slingshot projectiles, about whether the ancients possessed knowledge of infinitesimal mathematics - that is, "whether these Projectiles are the Result of an instinctive feeling of their makers for fitness or if they are proofs of the high State of Mechanical Science with the Greeks" [Mallgrave, Rykwert and Semper 1983: 13-14]. To be clear: Semper explicitly rejected 
the view that artistic forms could be calculated. In Ms. 124 and in the 1884 German translation of Semper's London lecture - but not in Ms. 122, the lecture he actually delivered - he referred to the formula as a "crutch" and stated that "results in fine arts are hardly obtainable by calculation" [Mallgrave, Rykwert and Semper 1983: 18]. In the slingshot text he also stated that it should "not be claimed that the Greeks constructed their forms on the basis of mathematical formulas." However, in the same sentence, he referred to infinitesimal terminology by stating that the Greeks "clearly recognized the law of nature that nature observes the extreme limits within her formations and lets tensions prevail everywhere" [Semper 1859: 60]. ${ }^{11}$

As early as 1834 , he declared that architecture was based "on indeterminable but for that reason no less certain and solid laws .... Although we are convinced of the existence of these laws, nevertheless we cannot determine them a priori with mathematics" [Semper 1834 (1991): 224]. Semper concluded that science was not yet advanced enough to express these complex laws of beautiful architecture but that an architect can feel them and achieve them through this feeling and must therefore strive to practice "the only criterion of their existence-the feeling for their excellence" [Semper 1834 (1991): 224]. In particular, he claimed that science lacked knowledge of the "vital force" (Lebenskraft $^{12}$ - that is, how life evolves and grows. According to Semper, the most interesting forms in nature are created by this force. And again, since science is not there yet, "we have no other Guides than our own natural feeling assisted by a right study of natural history and of that of art" [Mallgrave, Rykwert and Semper 1983: 14]. ${ }^{13} \mathrm{He}$ described this feeling as an unconscious differential and integral calculation by someone gifted with an aesthetic sense, since, as he says in "Ueber die formelle Gesetzmäßigkeit des Schmuckes und dessen Bedeutung als Kunstsymbol," "the impression that the form makes on our sense of beauty is at first founded on an unconscious measuring, weighing, and integrating of functions that are too complicated for our science and whose solutions can be achieved by it alone" [Semper (1884) 1979: 326]. ${ }^{14}$ It is very interesting to read that Semper sees integration better achieved by the sense of beauty than by calculation. The unfortunate aspect of this is, according to Semper, that

[the] more we advance in civilization and science the more it seems that that instinctive feeling ... loses its strength, while Science has not yet attained to the point, of compensating us for this loss. It very often happens, that we are led back by science and calculation to such forms, which were observed heretofore only by savages, and semibarbarians [Mallgrave, Rykwert and Semper 1983: 13].

Hence, all these texts on the subject served to demonstrate that an artistic feeling educated by science and history leads to more precise and more beautiful results than the scientific methods that had been developed by that time.

Semper also criticized the laws that had been proposed by earlier architects as insufficient, too schematic, and too rigid. In particular he accused Jean-Nicolas-Louis Durand of getting lost in tables, formulas, and mechanical ways of connecting things [Mallgrave, Rykwert and Semper 1983: 9]. In his text on leaden slingshot projectiles, Semper described his participation in a meeting of the Royal Institute of British Architects in London in which one member presented his findings on ancient laws of proportions, which in Semper's view were too schematic, simple, and absolute. "Does nature, does the artist's sense create like a wood turner according to a template?" he asked and replied that the physically beautiful depends on a wide variety of external conditions and is "only under certain circumstances truly beautiful and proportional, while under 
others it is - though its form and color remain unchanged - indifferent or ugly" [Semper 1859: 2-3]. In this context, he emphasizes the superiority of mathematical analysis of constant change and infinity as opposed to simple mathematics and the laws of proportion:

These determining circumstances are, however, subject to infinite variations, and therefore universally valid numerical rules of proportion for the beautiful cannot be specified. The formulas in which the true laws of beauty would be defined, (if it is possible at all to formulate the latter) may, in any case, only be treated as equations in which variable and constant values interact in the most diverse ways" [Semper 1859: 3].

So, whereas the simple laws of proportion could only give mechanical answers, for Semper infinitesimal calculus seemed to permit "organic" - that is, vital and complex insights.

This is not to say that rules of proportion, symmetry, harmony, and ornamentation lost their authority in Semper's understanding of architecture. Quite the opposite, since these rules were developed in the practical arts long before architecture [Mallgrave, Rykwert and Semper 1983: 9], they made their way into architecture as "motives," thus bringing us back to the question where in the functional equation the motives are represented: in the function sign $C$ (as interpreted by Hans Semper) or in the equation itself (as interpreted by Mallgrave). Regarding these rules as basic motives, Semper is able to explain them as valid in an abstract way, while they become concrete in measurable things only if confronted with the "coefficients" of specific purpose, material, place, artist, and all the other influences. ${ }^{15}$

Semper was driven by the effort to let science enter into architecture, but he did not try to do so in a schematic way, but rather by acknowledging the developments of history, culture, languages, and other influences. For that reason, Semper's concern when introducing science into art was not to simplify design or offer a recipe for design which is how he regarded Durand's writings - but rather to understand and reveal the richness of design processes more precisely. Hence Semper seemed to guard against a clearer formulation of his equation, which after all could only have been employed too mechanistically. One could also claim that Semper described his formula as a "crutch" not because he did not believe in a mathematical explanation of form but rather because he believed its complexity could not be formulated. Semper's text on leaden slingshot projectiles has to be evaluated in that context, as he was inspired to write it in order

to demonstrate with the simplest possible example that the Greeks did not merely observe the laws of nature and try to imitate forms evolved from them but rather had truly studied these laws and based on them, independently of all imitation, created their own forms, which coincided with those of nature only in terms of the commonality of the law [Semper 1859: 6].

\section{Mathematical functions}

The purpose of the following, more detailed discussion of the mathematical concept of function is to speculate about whether further insights for art and architecture can be derived from Semper's equation.

Infinitesimal calculus and the concept of function are, along with analytic geometry, the outstanding achievements of mathematics in the seventeenth century, authored by Isaac Newton and Gottfried Wilhelm Leibniz. The notation $f(x)$ derived from Leonhard 
Euler and was first published in 1740. In his famous Introductio in Analysin Infinitorum (Introduction to Analysis of the Infinite, E101) of 1748, Euler explained that "analysis is concerned with variable quantities and functions of such variables" [Euler 1888: vi], and his Institutiones Calculi Differentialis (Foundations of Differential Calculus, E212) of 1755 offered this definition:

Those quantities that depend on others in this way, namely, those that undergo a change when others change, are called functions of these quantities. This definition applies rather widely and includes all ways in which one quantity can be determined by others. Hence, if $x$ designates the variable quantity, all other quantities that in any way depend on $x$ or are determined by it are called its functions [Euler 2000: vi].

The development of mathematical analysis made possible the transition from calculation with constants to calculation with variables. Mathematicians have often regarded the variable as the true core of a function, whereby an input variable (what Semper calls "coefficient") is the independent variable, and the output variable (what Semper calls "result" or "work of art") is the dependent variable. A function $F$ is a correspondence rule, that is, a rule that produces an explicit relationship between an input variable $x$ and precisely one output variable $y$; in other words: from $x$ follows $y$, but $x$ does not follow from $y$. Transferred directly to Semper's formula, the "coefficients" determine the work of art but, conversely, a work of art can be traced back to various input variables (for example, a different climate, history, artist). It was only the fact that a mathematical function is dynamic when coefficients come into play that made it interesting for Semper's reflections on style. For Semper, different styles resulted from the variable coefficients: materials, national events, and individual architects or artists lead to material styles ("Wood Style"), national styles ("Egyptian Style"), styles of patrons ("Style of Louis XIV"), and artist's styles ("Style of Raphael"). ${ }^{16}$ In short, what he was attempting with his equation was nothing less than a model to explain his theory of style, according to which both the temporary coefficients and the timeless motives and early forms are necessary to create a style. In that spirit, in 1869 Semper wrote in "Ueber Baustile" (On Architectural Styles) that style "is the accord of an art object with its genesis, and with all the preconditions and circumstances of its becoming. When we consider the object from a stylistic point of view, we see it not as something absolute but as a result" [Semper (1869) 1989: 269]. The motives and early forms alone cannot be style. They are the forms that remain when the "coefficients" are removed - that is, everything on which all cultures are based. They are the timeless, the placeless, the artistless. From this it follows that "motive," "early form," and "design idea" are not variables but can only be the function itself. This understanding is what Ms. 124 explains and was therefore merged into the German translation by Hans Semper:

As soon as one or some of these coefficients vary, the result must vary likewise, if $x$ becomes $(x+a)$ the result will be $U$, quite a different one from that, which we call now $Y$; but it will in the principle remain identical to the last, being connected with it by a common relation which is expressed by the letter $C$. Likewise, if $x, y$, $z$, $t$ etc. remain the same but if $C$ changes, the $Y$ will change in an other manner than before. It will be fundamentally different from what it was before the change took place, although the coefficients $x, y, z, t, v$ etc. have undergone no change [Mallgrave, Rykwert and Semper 1983: 18]. 
Functions or correspondence rules specify how to calculate with variables. One of the advantages of this calculation is that one can follow what happens when different input values are entered for a variable. For example, the value "climate a" or "climate b" (if such a value could be determined at all) can be input into a variable and the different results compared. In other words, this process is very well suited to the comparative method. Infinitesimal calculus as a comparative method is one of Semper's extremely interesting ideas, but note that it should be understood as merely a theoretical conception, since in his view the variables were too complex and also impossible to determine numerically.

One core idea of infinitesimal calculus - and perhaps the most productive theme in its application to architecture and art - is the relationship of differentiation and integration of functions. From a historical perspective, this is about the connection between determining tangents and determining area: differentiation involves finding a tangent to a point on a curve, and integration involves finding the area contained within a curve. Leibniz and Newton had already recognized that there was an inverse connection between the two. The notion that integration could be derived from the inversion of differentiation survived into the nineteenth century [Wussing 2008: 1, 429 and 461468], while Johann Bernoulli had already aptly formulated the problem of integration as the inverse operation of differentiation in 1691-92:

But as easy it is to find the differential of any one provided quantity, so difficult is it conversely to specify the integral of any differential, so that we sometimes cannot even claim with certainty whether the integral can be formed of the provided quantity or not [Bernoulli 1914: 8].

If this theme is compared with Semper's two main architectural problems - namely, the classifications of works of architecture and the invention of them - it suggests the hypothesis that in Semper's way of thinking classification corresponds to differentiation and invention to integration. His writings can be interpreted to the effect that the operation of differentiation (classification) is intended to draw conclusions for integration (invention). This hypothesis is supported by Semper's remark that a comparative (and hence classifying) method similar to Cuvier's could

form the base of a doctrine of Style, and of a Sort of topic or Method, how to invent, which may guide us to find out the natural way of invention which would be more than could be allowed to the great Naturalist to do for his sublime science. $^{17}$

Seen in this way, his equation can be read in two directions. Read horizontally, the artist aims at the work of art/result (that is, the left side of the equation) and the theorist at the variables (the right side of the equation). Read vertically, the equation contains the search for style by means of integration and the search for motives and internal laws by means of differentiation. Semper studied works of art or results, and in the process determined the variables and ultimately derived the motives from them. In other words, Semper read the equation backward, with the result as the known quantity. Semper probably recognized the motives first in the four elements - hearth, roof, enclosure, and mound $^{18}-$ and later in the manufacturing processes of textile art, ceramics, tectonics, stereotomy, and metallurgy. Yet Semper, much like Bernoulli, recognized integration as a much greater challenge than differentiation. He reasoned that mathematics

can certainly calculate differentials of very complex functions but it rarely succeeds at integration, especially in physical cases where forces interact in 
complex ways according to laws that still need to be defined. But at least mathematics attempts such integration; indeed, it sees it as its most important task [Semper (1860) 2004: 80].

From what has been said thus far it should have become clear that Semper compared things in nature and works of art and made an analogy between them. Very much analogously to motives and coefficients in art, he wrote that Georges Cuvier's naturalist collection shows

progressing nature, with all its variety and immense richness, most sparing and economical in its fundamental forms and Motives; we see the same skeleton repeating itself continually, but with innumerable varieties, modified by gradual developments of the Individuals and by the conditions of existence which they had to fulfill [Mallgrave, Rykwert and Semper 1983: 8].

He concluded with the question: "may we not by Analogy assume, that it will be nearly the same with the creations of our hands, with the works of industrial art?" [Mallgrave, Rykwert and Semper 1983: 8].

Correspondingly, Semper's reflections on mathematics did not stop when observing nature. The mathematics of constant change, infinity, and variables permitted a dynamic perspective on nature whose complexity enabled it to serve as a model for art:

Nature works not like a turner after working drawings or what they call templates, its forms are altogether dynamical productions, and it is only by the way of that science, which treats of the mutual actions and reactions of forces, that we may hope to find the keys for some of the simplest material forms. What is true in Nature, has its application also for artistical forms [Mallgrave, Rykwert and Semper 1983: 15].

Semper's attempt to give a more scientific account of the factors that determine form was his modern contribution to the contemporaneous discourse on art as the imitation of nature.

One could add here that Semper's application of the concept of mathematical functions to architectural theory had its counterparts among the works of the theorists of natural history, who provided literal and metaphorical comparisons of organisms and equations of curves. For example, Georges Cuvier compared the relationship between a tooth and the other parts of a body to the way "the equation of a curve regulates all its other properties" [Cuvier 1818: 102], while Gottfried Leibniz wrote that there are special points of change in the life of a person which are part of a general path like "the distinctive points of a curve can be determined by its general nature or its equation" [Leibniz 1989: 658-659].

\section{Art and functional dependency}

The discussion has shown that both Hans Semper's and Harry Francis Mallgrave's readings of Gottfried Semper's equation result in productive theses. The question of which is the "correct" reading will be left open. In general, however, it can be concluded from both readings that "function" refers to a process, an active synthesis of all of the "influences" Semper described. Thus the equation testifies to Semper's central concern: understanding this synthesis, which is the richness of the design process, or, in Semper's words, 
to explore within individual cases the regularity and order that become apparent in artistic phenomena during the creative process of becoming and to deduce from that the general principles, the fundamentals of an empirical theory of art [Semper (1860) 2004: 71].

While a specific equation will never be found and the "power of a genius may subconsciously achieve such nature-like creation," he nevertheless asserted that it should be the task of a contemplating architect "to seek and pursue the rise and development of basic ideas and to reduce to its simplest expression the law that lies hidden within the artistic covering" [Semper (1855) 1984: 194].

Neither reading of the formula leads to a primitive determinism or materialism, for it is neither possible to determine the equation nor to provide a complete set of variables. Semper always fundamentally and vehemently opposed materialism. If Semper is regarded, on the basis of this equation, as a precursor to High Modernism, it is also necessary to acknowledge in his theory the internalization of history, artistic originality, symbolic motives, national interests, and the distinction between traditional/ideafounding purposes and current/specific purposes. The biggest criticism aimed at Semper for his equation was that the artist was degraded to just one variable among many. Herrmann in particular has described it as part of Semper's maturation process that in his later writings he attributed increasing significance to the creative human being [Hermann 1990: 80]. For example, in 1869, in "On Architectural Styles," Semper observed that

the free will of the creative human spirit is the first and most important factor in the question of the origin of architecture styles, although, of course, man's creative power is confined by certain higher laws of tradition, demand, and necessity. Yet man appropriated these laws and made them subservient, as it were, to his free, objective interpretation and exploitation [Semper (1869) 1989: 268].

This does not, however, bring down the equation, since a weighting of the different "coefficients" that the increasing significance of the artist would express is by no means the object of the equation. In the prolegomena to Style in the Technical and Tectonic Arts, Semper managed in one breath both to offer a mathematical-functional analogy and to emphasize "the sense and the purely human impulse of being creative as an end to itself and the gift - so indispensable to the artist as well as to people receptive to art - of direct intuitive thinking" [Semper (1860) 2004: 73]. Semper had always emphasized the superiority of artistic feeling and aimed at integrating poetic and scientific activity. Thus his formula should be interpreted as an attempt to grasp the world - including art and science - as a unity.

\section{Acknowledgments}

I would like to thank Hans Christian Poerschke for his insights and support concerning infinitesimal calculus. I would also like to thank Steven Lindberg for the main translation and the discussions about appropriate translations, which is a major question of this essay. All translations of original quotations provided in the text are by Steven Lindberg and Ute Poerschke unless otherwise noted.

\section{Notes}

1. See, for example, [Hauser 1985]. See also the discussion of the "comparative method" in architecture, anatomy, and linguistics in [Hvattum 2004: 114-136].

2. The original manuscripts are published in full in [Mallgrave, Rykwert and Semper 1983]. 
3. When reading the manuscript, one should keep in mind that Gottfried Semper's knowledge of English was limited at the time. The unusual capitalization in Mallgrave's publication of the text follows the manuscript.

4. There is no published English translation of Semper's Ueber die bleiernen Schleudergeschosse der Alten .... . An introduction to the text can be found in [Mallgrave 1996: 222-224]. See also [Herrmann 1984: 74].

5. In addition to the texts described, see "Bemerkungen zu des M. Vitruvius Pollio zehn Büchern der Baukunst” (1856), in [Semper (1884) 1979], esp. 203-204.

6. In Ms. 179, for example, Semper wrote of Zweck (purpose) and Zweckeinheit (unity of purpose), but then crossed out the relevant paragraphs and wrote anew of Idee (idea) and Inhaltsangemessenheit (appropriateness of content). See [Herrmann 1981: 226]. See also Mari Hvattum's comment on the "ambiguous role of 'purpose" in Semper's work [Hvattum 2004: 223, n. 95].

7. Semper offers this example in "Plan eines idealen Museums," in [Semper 1966: 72-79].

8. Later, in Style in the Technical and Tectonic Arts, Semper orders the coefficients again differently. The "technical arts" will be explored "from the following two points of view: 1 . The work as a result of the material service or use that is intended ... . 2. The work as a result of the material used to produce it, as well as of the tools and procedures applied. The use of any technical product remains essentially the same at all times. It is based on universal human needs and on natural principles seeking formal expression that are valid everywhere and at all times. But the materials used to make this product, and particularly how they are treated, change radically over time according to local and all other possible circumstances. It is thus appropriate to link more general formal-aesthetic considerations to the question of purpose and to link considerations of the history of style to materials. But we cannot expect to apply this principle with full consistency" [(1860) 2004: 107].

9. Ernst Stockmeyer discussed various interpretations; see [1939: 8].

10. See [Wussing 2008: I, 432]. Wussing emphasizes that master builder in hydraulics and fortifications, shipbuilders, mining and structural engineers profited from infinitesimal calculus

11. The complicated German sentence reads as follows: Mit dieser Bemerkung ... soll nicht behauptet sein, dass die Griechen ihre Formen nach mathematischen Formeln construirten, welches in der Kunst anzunehmen absurd wäre, sondern dass sie das Gesetz der Natur, wonach diese bei ihren Formgebungen die extremen Grenzen beobachtet und überall Spannungen herrschen lässt, nicht bloss dunkel ahnten, sondern klar erkannten [Semper 1859: 60].

12. See [Semper 1859: 4]. See also [Semper (1860) 2004: 90]. In Ms. 122 Semper named it "the power of animal and vegetable Life" [Mallgrave, Rykwert and Semper 1983: 14].

13. See also [Semper 1859: 4]: "Here we find ourselves in an area where at first no guide accompanies us other than our own artistic sense, supported by a healthy study of nature and art history."

14. See also Semper's commentary on Vitruvius, "Bemerkungen zu des M. Vitruvius Pollio zehn Büchern der Baukunst", in which he asserted that the sense of beauty alone is able "to integrate the most difficult and most transcendental dynamic problems and expressions from which our science shies away" [Semper (1884) 1979: 206].

15. See also Semper's remarks on Vitruvius [ (1884) 1979: 203-204], in which he explains the relationship of the basic rules of symmetry, proportion, and direction, on the one hand, and the external coefficients, on the other hand, through a "logarithmic analogy" (logarithmischen Gleichnisses).

16. See, for example, [Mallgrave, Rykwert and Semper 1983: 12] and "Ueber die formelle Gesetzmäßigkeit des Schmuckes und dessen Bedeutung als Kunstsymbol“" [Semper (1884) 1979: 343].

17. See [Mallgrave, Rykwert and Semper 1983: 9]. See also Ms. 55, "Influence of Historical Research on Trends in Contemporary Architecture": "It will certainly be important to trace these standard forms and the idea inherent in them. Not only will the overall view and the understanding of what exists be made easier, but it will also be possible to derive an architectural theory of design and inventiveness" [Hermann 1984: 195]. 
18. See "The Four Elements of Architecture" [Semper (1851) 1989]. Here the influences are not yet subdivided or worked out. He writes very generally: "According to how different human societies developed under the varied influences of climate, natural surroundings, social relations, and different racial dispositions, the combinations in which the four elements of architecture were arranged also had to change, with some elements becoming more developed while others receded into the background" [(1851) 1989: 103].

\section{References}

BERNOUlLI, Johann. 1914. Die erste Integralrechnung: eine Auswahl aus Johann Bernoullis mathematischen Vorlesungen über die Methode der Integrale und anderes. Gerhard Kowalewski, ed. and trans. Leipzig: Engelmann.

Börsch-Supan, Eva, et al. 1976. Gottfried Semper und die Mitte des 19.Jahrhunderts. Basel: Birkhäuser.

Cuvier, Georges. 1818. Essay on the Theory of Earth. Robert Jameson, trans. New York: Kirk \& Mercein.

EULER, Leonhard. 1988. Introduction to Analysis of the Infinite. John D. Blanton, trans. New York: Springer.

- 2000. Foundations of Differential Calculus. John D. Blanton, trans. New York: Springer.

Frege, Gottlob. (1891) 1980. Funktion und Begriff. Eng. trans: Function and Concept. Peter Geach and Max Black, trans. Pp. 21-41 in Translations from the Philosophical Writings of Gottlob Frege, 3rd ed., Peter Geach and Max Black, eds. Oxford: Blackwell.

Hauser, Andreas. 1985. Der 'Cuvier der Kunstwissenschaft': Klassifizierungsprobleme in Gottfried Sempers 'Vergleichender Baulehre.' Pp. 97-114 in Grenzbereiche der Architektur, Thomas Bolt, ed. Basel: Birkhäuser.

Herrmann, Wolfgang. 1976. Semper und Eduard Vieweg. Pp. 199-237 in Eva Börsch-Supan, et al., Gottfried Semper und die Mitte des 19. Jahrhunderts. Basel: Birkhäuser.

. 1978. Gottfried Semper im Exil. Basel: Birkhäuser.

- 1981. Gottfried Semper: Theoretischer Nachlass an der ETH Zürich; Katalog und Kommentare. Basel: Birkhäuser.

- 1984. Gottfried Semper: In Search of Architecture. Cambridge, MA: MIT Press.

1990. Sempers Weg von der Mathematik zur vergleichenden Baulehre. Pp. 73-81 in Bildfälle: Die Moderne im Zwielicht, Beat Wyss, ed. Zurich: Artemis.

Hvattum, Mari. 2001. Gottfried Semper: Between Poetics and Practical Aesthetics. Zeitschrift für Kunstgeschichte 64: 537-46.

. 2004. Gottfried Semper and the Problem of Historicism. Cambridge, UK: Cambridge Univ. Press.

JAHNKE, Hans Niels. 1999. Geschichte der Analysis. Heidelberg: Spektrum.

LAUDEL, Heidrun. 1991. Gottfried Semper: Architektur und Stil. Dresden: Verlag der Kunst.

LeIBNIZ, Gottfried Wilhelm. 1989. Philosophical Papers and Letters, 2nd ed. Leroy E. Loemker, ed. and trans. Dordrecht: Kluwer.

Mallgrave, Harry Francis. 1996. Gottfried Semper: Architect of the Nineteenth Century. New Haven, CT: Yale University Press.

Mallgrave, Harry Francis, Joseph Rykwert, and Gottfried Semper. 1983. London Lecture of November 11, 1853. RES: Anthropology and Aesthetics 6: 5-31.

SEMPER, Gottfried. (1834) 1991. Dresdner Antrittsvorlesung 1834. Pp. 221-34 in Heidrun Laudel, Gottfried Semper: Architektur und Stil. Dresden: Verlag der Kunst.

_. (1851) 1989. Die vier Elemente der Baukunst. Eng. trans: The Four Elements of Architecture. Pp. 74-129 in Gottfried Semper, The Four Elements of Architecture and Other Writings. Harry Francis Mallgrave and Wolfgang Herrmann, trans. Cambridge: Cambridge University Press.

_. (1852) 1989. Wissenschaft, Industrie und Kunst: Vorschläge zur Anregung nationalen Kunstgefühles. Eng. trans: Science, Industry, and Art. Pp. 130-167 in Gottfried Semper, The Four Elements of Architecture and Other Writings, Harry Francis Mallgrave and Wolfgang Herrmann, trans. Cambridge: Cambridge University Press. 
(1855) 1984. Theorie des Formell-Schönen. Eng. trans: The Attributes of Formal Beauty. Pp. 219-244 in Gottfried Semper, In Search of Architecture. Wolfgang Hermann, ed. Cambridge, MA: MIT Press.

1859. Ueber die bleiernen Schleudergeschosse der Alten und über zweckmässige Gestaltung der Wurfkörper im Allgemeinen: Ein Versuch die dynamische Entstehung gewisser Formen in der Natur und in der Kunst nachzuweisen. Frankfurt: Verlag für Kunst und Wissenschaft.

- (1860) 2004. Der Stil in den technischen und tektonischen Künsten; oder, Praktische Aesthetik; Ein Handbuch für Techniker, Künstler und Kunstfreunde Vol. 1: Textile Kunst. Eng. trans: Style in the Technical and Tectonic Arts; or, Practical Aesthetics. Harry Francis Mallgrave and Michael Robinson, trans., Harry Francis Mallgrave, ed. Los Angeles: Getty Research Institute.

- (1869) 1989. Ueber Baustile. Eng. trans: On Architectural Styles. Pp. 264-284 in Gottfried Semper, The Four Elements of Architecture and Other Writings. Harry Francis Mallgrave and Wolfgang Herrmann, trans. Cambridge: Cambridge University Press.

—_. (1884) 1979. Kleine Schriften. Ed. Hans and Manfred Semper. Mittenwald: Mäander.

1966. Wissenschaft, Industrie und Kunst und andere Schriften über Architektur, Kunsthandwerk und Kunstunterricht. Hans M. Wingler, ed. Berlin: Kupferberg.

1989. The Four Elements of Architecture and Other Writings. Harry Francis Mallgrave and Wolfgang Herrmann, trans. Cambridge: Cambridge University Press.

STOCKMEYER, Ernst. 1939. Gottfried Sempers Kunsttheorie. Zurich: Rascher.

Wussing, Hans. 2008. 6000 Jahre Mathematik: Eine kulturgeschichtliche Zeitreise, 2 vols. Berlin: Springer.

\section{About the author}

Ute Poerschke has been an Associate Professor in the Department of Architecture at The Pennsylvania State University, USA, since 2006. She taught at the Technical Universities of Berlin and Munich, Germany (1999-2005), and completed her doctoral degree in architectural theory about interpretations of functionalism at the Technical University of Cottbus in 2005. Her teaching areas include architectural design, technical systems integration, and architectural theory. She has been a principal of the architectural firm Friedrich-Poerschke-Zwink Architekten, Munich, since 2004. Her research interests are in the fields of theory, practice and teaching of architectural design as a process of integration. 